\title{
Formal and Informal Knowledge Sharing in Organisations from Slovakia and Hungary
}

\author{
Andrea Bencsik, Tímea Juhász, Ladislav Mura, Ágnes Csanádi
}

\begin{abstract}
A B S T R A C T
Objective: The purpose of the research is to investigate whether leaders deal with the impact of informal knowledge sharing (workplace gossip) on organisational performance or not.

Research Design \& Methods: A quantitative survey (questionnaire survey) was conducted and SPSS was applied to evaluate the research results. The next phase of the research focused on preparing case studies, with a specific aim to identify the role and impact of workplace gossip.
\end{abstract}

Findings: The research results show that workplace gossip (informal knowledge sharing) has a significant impact on work, but the consequences of gossip are not addressed efficiently in theory and practice. Organisations recognize the need for knowledge management on a strategic level and they use the appropriate tools, but the gossip as an informal communication method is not accepted. Businesses are not concerned with the consequences of gossip; they never try to quantify its economic impacts.

Implications \& Recommendations: Gossip is an essential part of the culture worldwide, even if the manifestation of it is different. The opposite result is achieved if workplace gossip is prohibited or punished by the management. The goal is to achieve positive benefits that will be visible when the economic impact of gossiping can be confirmed.

Contribution \& Value Added: There is a lack of scientific work addressing the economic consequences of gossip in different situations in organisations. The economic effects of gossip can be calculated not only in KMSs, but might be applied for other processes in the organisation.

\begin{tabular}{|c|c|}
\hline $\begin{array}{l}\text { Article type: } \\
\text { Keywords: }\end{array}$ & $\begin{array}{l}\text { research article } \\
\text { consequences of gossip at workplaces; gossip; informal knowledge; } \\
\text { knowledge management; knowledge sharing }\end{array}$ \\
\hline JEL codes: & $\mathrm{M} 12, \mathrm{O} 15$ \\
\hline Received: 1 & Accepted: 25 July 2019 \\
\hline
\end{tabular}

\section{Suggested citation:}

Bencsik, A., Juhász, T., Mura, L., \& Csanádi, Á. (2019). Impact of Informal Knowledge Sharing for Organizational Operation. Entrepreneurial Business and Economics Review, 7(3), 25-42. https://doi.org/10.15678/EBER.2019.070302 


\section{INTRODUCTION}

The operation of knowledge management systems (KMS) - appreciation of knowledge and knowledge sharing in terms of organisational operation - is becoming more and more emphasized, not only in everyday life of organisations or management thinking but also the scientific literature is addressing the reader with new theoretical models, practical solutions, case studies and best practices.

The most critical issue both in theory and organisational practice is acquiring the right knowledge and sharing it in the organisation. There are several tools available to accomplish it, but the organisational culture as a prerequisite influences the choice of tools and their application in accordance with the objectives. Knowledge sharing is much more effective in this type of organisational culture (Lorincová, 2018; Volek \& Novotná, 2016). Beside formal solutions, informal solutions play an essential role as well, if not even more efficient tools to meet the objective (Novotná \& Volek, 2018).

This article does not provide possible solutions for knowledge management systems and knowledge sharing, but addresses the issue in general.

The research questions were formulated on the basis of earlier research and theoretical considerations.

- RQ1: How typical is formal and informal knowledge sharing in organisations?

- RQ2: Is gossip used as an informal tool of knowledge sharing?

- RQ3: Does the real content of information to be shared affect the use of gossip?

- RQ4: Do we transfer professional or non-professional content via gossiping?

- RQ5: How does workplace gossip affect organisational performance?

- RQ6: Do leaders at workplaces address the organisational impact of gossip?

Hypotheses were formulated to answer the research questions.

The addressed issue is important since gossip is an essential part of culture worldwide, even if the manifestation of it is different. The opposite result is achieved if gossip is prohibited or punished by the management. The goal is to achieve positive benefits that will be visible if the economic impact of gossiping can be confirmed.

There are not enough scientific papers focusing on models and methods of calculating the economic consequences of workplace gossip. This article is trying to address the issue. The economic effects of gossip can be calculated not only in knowledge management systems, but might be applied for other processes in the organisation.

At first, we review the scientific background that served as a basis to formulate the research hypotheses. This is followed by the presentation of the research method. The third chapter discusses the research results. Finally, a comparison to earlier data is provided, as well as the research results are summarised.

\section{LITERATURE REVIEW}

To clarify the issue of knowledge management (KM), the model of Probst et al. (2006) is presented, that illustrates the relationship between the elements of one of the most useful knowledge management systems and their logical interrelations. This model is very popular in the KM practice. The logic of our research is based on this model. 
Building on the problematic nature of knowledge acquisition and knowledge sharing, the research focus was determined according to the phases of possible solutions. The research addressed workplace gossip as an informal tool of knowledge sharing. Based on the theoretical foundations of the issue, the research analysed everyday practice of organisations. We wanted to know whether managers of organisations address the issue of workplace gossip in economic terms. The results of a quantitative survey show that gossip has significant relevance and impact on work but the issue is not addressed either on the theoretical or the practical level. The consequences of workplace gossiping are not evaluated.

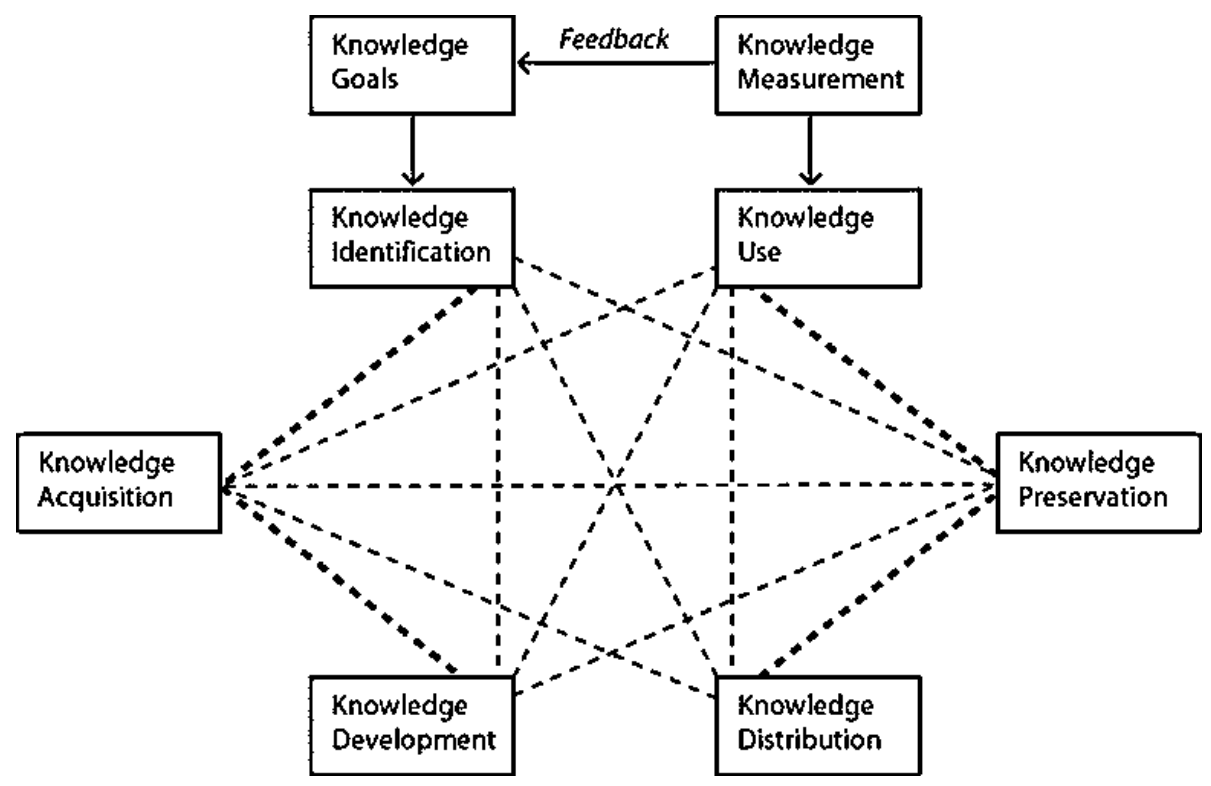

Figure 1. Probst model

Source: Probst et al., 2006.

\section{Informal Knowledge Sharing: Workplace Gossip}

Gossip is a part of everyday life, but rarely is the phenomenon in the focus of research. The issue is primarily addressed by communication professionals, psychologists, sociologists and behaviourists. Only a few studies deal with the impact of workplace gossiping on the functioning of the organisation, as well as it is rarely considered to be an expected managerial task or a part of it.

Part of the research focuses on organisational interests in terms of market participation - gossips about the organisation (Cuervo-Cazurra \& Ramamurti, 2014; Seilerová, 2019). Some of multinational companies monitor the news regularly and react immediately if they feel their activity and the company performance is threatened and the image of the organisation might be tarnished (Kiymaz, 2001). The fact supports the opinion that this form of informal knowledge sharing has economic consequences, pro and contra. At the same time, we have not found any research conducted that would specifically examine the consequences of workplace gossip (even in economic terms), although the importance of it is undisputable. 
Only in those extreme cases we can read about the consequences of gossip (primarily negative in tabloid newspapers), when there is a significant organisational conflict or an economic problem (Babalola et al., 2019). Although these cases are not clearly related to the consequence of gossip, they rather emerge as a consequence of complex problems in close association with workplace gossip.

Some definitions will be provided in terms of the professional perspective that will be an object of criticism below. According to the explanatory dictionary, gossip is "a casual or unconstrained conversation or reports about other people or their private life; an indiscrete, irresponsible information that is socially and ethically misleading." Negative characteristics are used when describing gossip, but the meaning of this term cannot be restricted to negative aspects (Michelson et al., 2010; Grosser et al., 2012; Georganta et al., 2014).

Other researchers defined gossip as a kind of social information about the person who is not present (Grosser et al., 2010). Gossip can be an important tool for people to get information about others or cope with social networks in their private life and workplaces as well (http://eletmod.transindex.ro/?hir=9458; Ellwardt et al., 2012). This definition approaches the term "gossip" with more tolerance, less negative aspects of the meaning are reflected.

When gossiping, we talk about others and judge people who are not present (the message is not necessarily negative). This form of communication makes a significant part of our personal interactions. We generally associate pejorative feelings with gossiping, but according to research in the field of social science, gossip plays an essential role in ensuring social order, cooperation, as well as maintaining the social and organisational standards (Beersma \& Van Kleef, 2012; Tassiel et al., 2018).

For several centuries, gossip has been associated with an unconstrained conversation that undermines the reputation of others. According to some research, e.g. at University of California, gossiping has some advantages as well (Feinbert et al., 2012). Based on the study of Feinbert and Willer "Gossip is an essential element to maintain the social order" (Feinbert \& Willer, 2010). It is not only important to evaluate the positive effects, but considerations are made also in terms of health. Our heartbeat will speed up immediately we hear bad news, which will optimize if we have someone to share the news with. This is the way we can reduce the negative impact of bad news. This fact confirms the positive consequences of gossip. Our research addressed gossip in social terms. We might assume that the transfer of negative information has an individual and social benefit as well (http://mipszi.hu/hir/120503-pletyka-jotekony-hatasai).

If gossip is filled with negative content, the effect can be contra-productive. Gossiping will only have a beneficial effect until it becomes damaging, harmful and an obsession. We hope that such behaviour is not accepted in workplaces. some additional research results about the power of gossip are worth mentioning, especially how it might influence human behaviour and thinking (Hitka et al., 2017; Bodnar, 2016).

Gossip has a manipulative power according to British authors who published their study in the scientific journal of the British Scientific Academy (http://eletmod.transindex.ro/?hir=9458). An experiment was made with the participation of young people, who were given money during the game and could pass it on to a player they wanted. The players were given different characteristics. The players showed willingness to pay less money to those with negative characteristics and more to those with positive features. 
In the next phase of the research, the students were made aware of people's real decisions. They were also introduced to lies that contradict facts. In this case, the students showed more willingness to give money based on gossip rather than make a decision based on facts. These experiments also confirm the power of this type of information transfer (http://eletmod.transindex.ro/?hir=9458).

The above examples clearly show the impact of gossip on the behaviour of communities and provide an explanation for the relationship between individuals and the health of the individual.

Why do we gossip? Gossip provides information about the human environment. It is not certain if everybody will pass on the gossip. If they do, some modification of the content is detected. Passing on gossip is possible, if the appropriate person to pass on the gossip is found at the appropriate time. Further condition is to make the fake news acceptable by combining facts and unreal information. It should also be acceptable for the community. Trust plays an important role since we pass on the information to someone we trust (Lazányi \& Fulop, 2017). At this point, a similarity can be detected in the case of research results connected with knowledge sharing. Knowledge transfer is successful if there is trust between the partners.

Nobody can question the existence of workplace gossip. Whether gossiping is harmful or supportive in terms of workplace performance and the relationship between employees might be disputable in the phase of knowledge acquisition and knowledge transfer (Vlacseková, 2019). Sometimes it is difficult to decide whether information exchange is a simple innocent chat, harmful gossiping or the transfer of positive news. While chat is a neutral activity, gossiping is negative and unpleasant to the person we are talking about. About $90 \%$ of human communication is considered to be gossip. It means that we are likely to initiate or/and listen to gossip. It is important to know that not only whispering in the corridor, but also $15 \%$ of the workplace correspondence can be considered gossip. Negative rumour occurs 2.7 times more in workplace correspondence than positive news (Chena \& Ayoun, 2019).

It is of great importance to develop and maintain appropriate communication channels in the workplace that not only increase the workplace performance but have an impact on the behaviour and well-being of employees. In companies with weak formal internal communication channels, the importance of informal communication channels is stronger and fills the gap of adequate channels for information flow. News and gossip are easier accessible when applying informal communication channels. One of the most frequent cases when gossip starts in the organisation is the period of organisational changes. Inadequate information combined with fake news and gossip can start an avalanche in the organisation. Uncertainty associated with changes in the organisation might result in hunger for information. The role of leaders is to fill this gap with adequate information about the changes and facts before fake news generated by employees can spread in the organisation. If the leader shares information with subordinates, even if the information is unpleasant, it is less likely the employees turn to be victims of the workplace gossip. If the employees are regularly informed by the leader, the occurrence and impact of gossip will be minimised.

The impact of gossip addressing workplace problems can influence performance as a result of worsening personal relationships. Open communication of leaders and the be- 
havioural pattern can minimise the occurrence and spread of gossip, referring to the undesirable nature of workplace conditions. The question is whether it is necessary to prevent workplace gossiping? As it was said above, gossip might have positive consequences on the workplace environment as well. According to the research conducted by Stanford University, gossip can stimulate cooperation and highlight the performance of good workforce. Gossiping can fulfil important functions in the community. Since numerous research proved pro and contra consequences of gossip in private life, not enough research results can we find about the importance of gossip in the workplace environment.

The appreciation of the importance of knowledge management systems also emphasizes the importance of knowledge acquisition and knowledge sharing. Both for knowledge acquisition and knowledge sharing, formal and informal methods of communication play an essential role. Thus, workplace gossiping as a form of informal knowledge sharing has a more prominent role than before. This fact contributed to the research examining the role of gossip as an informal tool of knowledge sharing.

To answer the research questions, based on theoretical background and personal experience, the following hypotheses were set:

H1: Employees prefer formal knowledge sharing in the workplace (Hitka et al., 2017; Bodnar, 2016).

H2: When sharing professional information, employees pay attention to trustworthy content of the information, while it is less important for sharing personal information. (Lazányi \& Fulop, 2017; Beersma \& Van Kleef, 2012; Tassiel et al., 2018).

H3: Gossiping has a negative impact on the organisation (Babalola et al., 2019; Chena \& Ayoun, 2019).

Gossip as a part of human nature is present in different cultures. The frequency of gossip and the characteristic features of sharing it, but also the possible consequences are influenced by cultural features. The characteristics of the two nations involved in the survey are very similar because respondents from Slovakia are fundamentally Hungarian people. They are Hungarians living in Slovakia. Their cultural characteristics are based on the same historical background. Behavioural differences can arise as a result of the social environment. The research sample was collected in both of the countries and joint evaluation of the achieved results was conducted.

\section{MATERIAL AND METHODS}

In 2018, a cross-national quantitative survey was conducted to find out what the opinion of respondents was about the economic significance of formal and informal knowledge sharing in organisations. The survey was conducted in Hungary and Slovakia in the form of online questionnaires (CAWI). We used snowball sampling and the same questionnaire was applied in both countries.

The research questions were closed, based on nominal and metric scales. The authors applied a 5-point Likert scale ( $1=$ not characteristic at all, $5=$ the most characteristic). The respondents were able to identify the given variable easily and realistically in reflection to their organisational practice. The authors used single-and multivariate statistical methods, e.g. frequency and average analysis, linear regression. 
The survey was voluntary and anonymous. We applied four various question groups (Table 1).

Table 1. Questionnaire structure

\begin{tabular}{|c|c|c|c|}
\hline Question group 1 & Question group 2 & Question group 3 & Question group 4 \\
\hline $\begin{array}{l}\text { Organisational speci- } \\
\text { fication }\end{array}$ & $\begin{array}{l}\text { Formal and informal } \\
\text { work-related infor- } \\
\text { mation and } \\
\text { knowledge sharing }\end{array}$ & $\begin{array}{l}\text { Transfer of trustwor- } \\
\text { thy and misleading } \\
\text { information and } \\
\text { knowledge }\end{array}$ & Gossiping \\
\hline $\begin{array}{l}\text { Location of the or- } \\
\text { ganisation, size, in- } \\
\text { dustry, ownership } \\
\text { Assessing the im- } \\
\text { portance of } \\
\text { knowledge }\end{array}$ & $\begin{array}{l}\text { Formal methods } \\
\text { Informal methods } \\
\text { Individuals sharing in- } \\
\text { formation } \\
\text { Content of the infor- } \\
\text { mation to be shared }\end{array}$ & $\begin{array}{l}\text { Cases of transmitting } \\
\text { professional vs non- } \\
\text { professional, trust- } \\
\text { worthy and mislead- } \\
\text { ing information and } \\
\text { knowledge }\end{array}$ & $\begin{array}{l}\text { Definition of gossip } \\
\text { Gossip content } \\
\text { Professional and non- } \\
\text { professional gossip } \\
\text { Effects of gossip } \\
\text { Perception of gossip }\end{array}$ \\
\hline
\end{tabular}

\section{Research Sample and Methodology}

The snowball sampling method applied is neither transparent nor representative. The Slovak sample consisted of 435 and the Hungarian included 310 organisations $(n=745)$. The respondents in Slovakia were the Hungarian minority. The company specifications by countries are presented in Table 2.

Table 2. Specification of the examined companies by countries

\begin{tabular}{|c|c|c|}
\hline Categories & Hungarian & Slovak \\
\hline Number of respondents & $310(100 \%)$ & $435(100 \%)$ \\
\hline \multicolumn{3}{|c|}{ Company size } \\
\hline Micro & $20.8 \%$ & $26.3 \%$ \\
\hline Small & $19.5 \%$ & $26.3 \%$ \\
\hline Medium-sized & $23.9 \%$ & $26.8 \%$ \\
\hline Large & $35.8 \%$ & $20.6 \%$ \\
\hline Ownership \\
\hline Domestic & $52.2 \%$ & $64.6 \%$ \\
\hline Mixed (domestic + foreign) & $15.1 \%$ & $21.5 \%$ \\
\hline Foreign & $27.7 \%$ & $13.9 \%$ \\
\hline $\begin{array}{c}\text { 8.2\% Education } \\
\text { 8.8\% Health and social care }\end{array}$ & $11.5 \%$ Trade. Repair \\
\hline $\begin{array}{c}\text { 6.9\% Construction industry } \\
\text { 8.8\% Trade. Repair }\end{array}$ & $11 \%$ Education \\
\hline & $7.2 \%$ Health and social care \\
\hline
\end{tabular}

Source: own study.

Variables used for the calculation can be seen in Table 3. 
Table 3. The role and meaning of variables

\begin{tabular}{|c|c|c|c|}
\hline \multirow{2}{*}{ Variables } & \multicolumn{2}{|c|}{ Variables } & \multirow{2}{*}{ Meaning of variables } \\
\hline & Independent & Dependent & \\
\hline $\begin{array}{l}\text { Professional } \\
\text { knowledge* }\end{array}$ & $\mathrm{X}$ & $\mathrm{x}$ & $\begin{array}{l}\text { Knowledge and information needed to do tasks in } \\
\text { workplaces }\end{array}$ \\
\hline $\begin{array}{l}\text { Private } \\
\text { information* }\end{array}$ & $\mathrm{x}$ & $\mathrm{x}$ & $\begin{array}{l}\text { Personal information not connected with official } \\
\text { tasks }\end{array}$ \\
\hline Not real content* & $\mathrm{X}$ & $\mathrm{X}$ & Information is (probably) not true. \\
\hline Real content* & $\mathrm{X}$ & $\mathrm{X}$ & Information is true \\
\hline Gossiping * & $\mathrm{X}$ & $\mathrm{X}$ & A conversation with personal information content \\
\hline $\begin{array}{l}\text { Organisational } \\
\text { performance* }\end{array}$ & & $\mathrm{x}$ & $\begin{array}{l}\text { Organisational performance reflects how success- } \\
\text { fully an organised group of people with a particular } \\
\text { purpose performs a function }\end{array}$ \\
\hline
\end{tabular}

Source: own study.

\section{RESULTS AND DISCUSSION}

\section{Research Results}

In order to verify hypothesis $\mathrm{H} 1$, the first question the authors had to clarify was the extent to which formal and informal knowledge sharing is typical in the organisation. Formal transfer of knowledge was more typical, with an average of 3.5 being calculated for the overall sample, which means that this type of knowledge transfer is frequent. In the case of examining informal knowledge sharing, the average of the sample was lower than that of the formal type of information sharing (average: 3.34). Employees are more likely to choose a formal way of information transfer.

The researchers used linear regression analysis. In the case of formal knowledge sharing professional information transfer with real content was investigated. In the case of informal knowledge sharing, the professional and not professional knowledge transfer was analysed. In both cases, knowledge transfer was analysed when information had both real and unreal content. Gossip was also examined, whether it has or not influence on organisational performance. The path model is presented in Figure 3.

Table 4 shows the results using the path model. In the case of a formal style of information sharing, two variants were analysed by the authors: professional and non-professional information. They examined how the nature of information affects the formal knowledge sharing. The linear model was significant in both cases, which means a correlation can be detected between professional knowledge and the formal way of knowledge transfer. In the case of the correlation between the elements of thinking scheme, $23 \%$ is proved to be relatively high (Barna \& Székelyi, 2008). In the case of non-professional information, the value of $r^{2}$ is lower than $1 \%$. There is no linear relationship demonstrated.

As for the hypothesis $\mathrm{H} 2$, the respondents primarily share professional information, differences can be detected between the Hungarian and Slovak companies ( $t$ : $2.701 \mathrm{df}$ : 743 sign.: $0.007 \mathrm{p}<0.05)$. It was more typical for the employees of the Hungarian companies (average: 3.57 ) than the Slovak ones (average: 3.37 ). In the case of informal knowledge transfer, the same variables were examined in terms of linearity. The explained ratio in the case of professional information was around $8 \%$. It shows that the 
linear line did not fit the scatter plot, the informal character of passing on professional information happens relatively slightly. A weaker fit can be detected in the case of nonprofessional information $\left(r^{2}: 01\right)$. It means that the participants of the survey did not really share private information in this form.

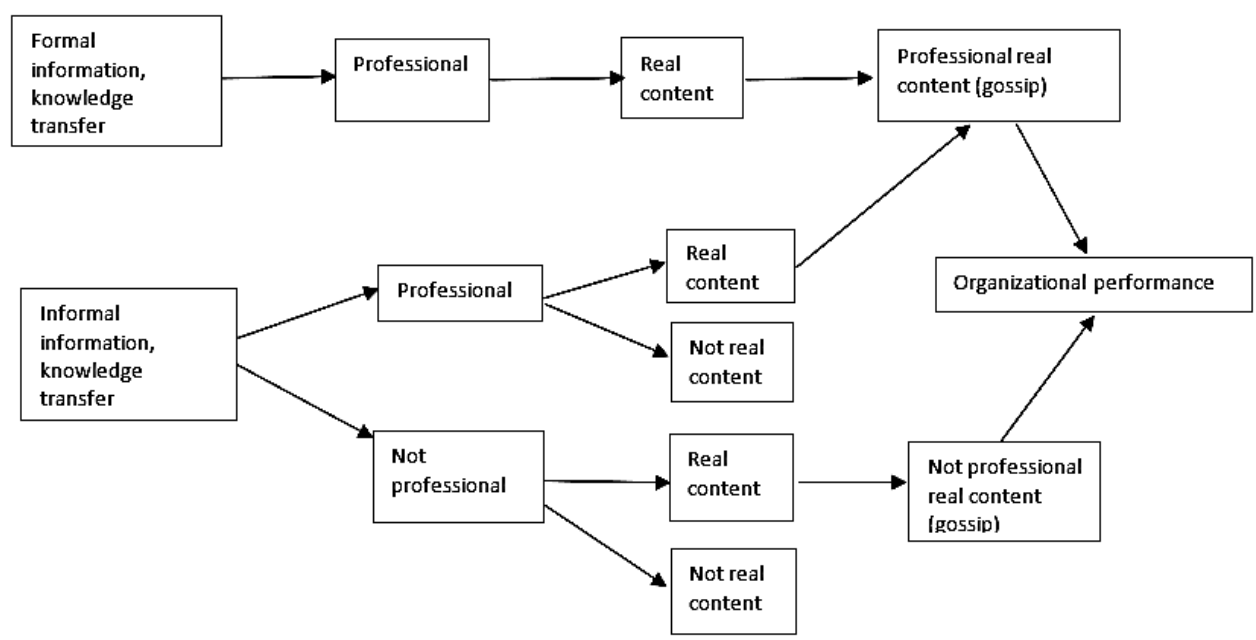

Figure 2. Path model

Source: own elaboration.

A question arouse whether we always pass on professional information, whether the willingness to share this type of information depends on the fact that the information to be communicated has real content or not.

Based on the content of the formally passed on professional information, if the real content of information was absent, the linear relationship could not be detected, while in the case of real content we could calculate with a high ratio $\left(r^{2}: 0.38\right)$. We use a formal way to pass on professional information. There was relatively high willingness to share real content information in a formal way in both of the countries. (Hungarian average 3.65; Slovak average 3.43). The Hungarian respondents showed more significant willingness than the Slovak ones ( $t: 2.896 \mathrm{df}: 0.743$ sign.: $0.004 \mathrm{p}<0.05$ ).

The formal transfer of private information was not examined by the researchers since it has not been proved that private information is transferred this way.

In the case of informal information sharing, the real content of professional information is transmitted $\left(r^{2}: 0.42\right)$. Similar is the experience with sharing private information $\left(r^{2}: 0.47\right)$. We are less likely to share private information with fake content $\left(r^{2}: 0.20\right)$.

Participants of the research share professional knowledge informally. A significant number of Hungarian respondents follow the mentioned practice (Hungarian average: 3.26; Slovak average 3.08). Slovak employees proved to be motivated in transferring personal data (Hungarian average: 2.65; Slovak average: 2.68 ).

Respondents use gossip as a form of information sharing in case of real professional and non-professional content, while do not share unreal information this way. The authors examined the impact of gossiping on organisational performance. The results show that 
information transfer based on real content gossiping has impact on performance, but its influence is minimal. The results are presented in Table 4.

Table 4. Results of Linear Regression $p=0.05$

\begin{tabular}{|c|c|c|c|c|c|c|c|c|c|}
\hline \multicolumn{2}{|c|}{ Parameters } & \multicolumn{5}{|c|}{ Model Summary } & \multirow{2}{*}{$\begin{array}{l}\text { Stand- } \\
\text { ardized } \\
\text { Coeffi- } \\
\text { cients } \\
\text { Beta }\end{array}$} & \multicolumn{2}{|c|}{$\begin{array}{l}\text { Unstandardised } \\
\text { Coefficients }\end{array}$} \\
\hline Independent & Dependent & $r^{2}$ & $\mathbf{F}$ & df1 & df2 & Sig. & & Constant & b1 \\
\hline $\begin{array}{l}\text { Professional } \\
\text { knowledge }\end{array}$ & Formal & 0.226 & 216.751 & 1 & 743 & 0.000 & 0.475 & 1.849 & 0.459 \\
\hline $\begin{array}{l}\text { Private infor- } \\
\text { mation }\end{array}$ & Formal & 0.004 & 3.019 & 1 & 743 & 0.083 & 0.064 & 2.287 & 0.060 \\
\hline $\begin{array}{l}\text { Not real con- } \\
\text { tent }\end{array}$ & $\begin{array}{l}\begin{array}{l}\text { Formally/ Profes- } \\
\text { sional information }\end{array} \\
\end{array}$ & 0.001 & 0.800 & 1 & 743 & 0.371 & -0.033 & 2.020 & -0.035 \\
\hline Real content & $\begin{array}{l}\begin{array}{l}\text { Formally/ Profes- } \\
\text { sional information }\end{array} \\
\end{array}$ & 0.381 & 456.501 & 1 & 743 & 0.000 & 0.617 & 1.462 & 0.597 \\
\hline $\begin{array}{l}\text { Professional } \\
\text { knowledge }\end{array}$ & Informal & 0.076 & 60.782 & 1 & 743 & 0.000 & 0.275 & 2.458 & 0.281 \\
\hline $\begin{array}{l}\text { Private infor- } \\
\text { mation }\end{array}$ & Informal & 0.014 & 10.850 & 1 & 743 & 0.001 & 0.120 & 3.021 & 0.122 \\
\hline $\begin{array}{l}\text { Not real con- } \\
\text { tent }\end{array}$ & \begin{tabular}{|l|} 
Informal/Profes- \\
sional information
\end{tabular} & 0.029 & 22.273 & 1 & 743 & 0.000 & 0.171 & 1.341 & 0.190 \\
\hline Real content & \begin{tabular}{|l|} 
Informal/Profes- \\
sional information
\end{tabular} & 0.415 & 527.298 & 1 & 743 & 0.000 & 0.644 & 1.176 & 0.662 \\
\hline $\begin{array}{l}\text { Not real con- } \\
\text { tent }\end{array}$ & \begin{tabular}{|l|} 
Informal/ Private \\
information
\end{tabular} & 0.204 & 190.372 & 1 & 743 & 0.000 & 0.452 & 0.568 & 0.473 \\
\hline Real content & $\begin{array}{l}\text { Informal/ Private } \\
\text { information }\end{array}$ & 0.471 & 660.680 & 1 & 743 & 0.000 & 0.686 & 0.816 & 0.720 \\
\hline Gossiping & $\begin{array}{l}\text { Formal /Profes- } \\
\text { sional infor- } \\
\text { mation/ Not real } \\
\text { content }\end{array}$ & 0.005 & 3.817 & 1 & 743 & 0.051 & 0.071 & 3.398 & -0.074 \\
\hline Gossiping & $\begin{array}{l}\text { Formal /Profes- } \\
\text { sional infor- } \\
\text { mation/ Real con- } \\
\text { tent }\end{array}$ & 0.059 & 46.706 & 1 & 743 & 0.000 & 0.243 & 2.296 & 0.273 \\
\hline Gossiping & $\begin{array}{l}\text { Informal/Profes- } \\
\text { sional infor- } \\
\text { mation/ Not real } \\
\text { content }\end{array}$ & 0.003 & 1.869 & 1 & 743 & 0.172 & 0.050 & 3.356 & -0.051 \\
\hline Gossiping & $\begin{array}{l}\text { Informal/Profes- } \\
\text { sional infor- } \\
\text { mation/ Real con- } \\
\text { tent }\end{array}$ & 0.032 & 24.239 & 1 & 743 & 0.000 & 0.178 & 2.625 & 0.194 \\
\hline Gossiping & $\begin{array}{l}\text { Informal/Private } \\
\text { information/ Not } \\
\text { real content }\end{array}$ & 0.003 & 1.970 & 1 & 743 & 0.161 & -0.151 & 3.358 & -0.055 \\
\hline
\end{tabular}




\begin{tabular}{|l|l|c|c|c|c|c|c|c|c|}
\hline \multicolumn{2}{|c|}{ Parameters } & \multicolumn{9}{|c|}{ Model Summary } & & $\begin{array}{c}\text { Stand- } \\
\text { ardized } \\
\text { Coeffi- } \\
\text { cients }\end{array}$ & $\begin{array}{c}\text { Unstandardised } \\
\text { Coefficients }\end{array}$ \\
\hline Independent & \multicolumn{1}{|c|}{ Dependent } & $\mathbf{r}^{2}$ & F & df1 & df2 & Sig. & Beta & Constant & b1 \\
\hline Gossiping & $\begin{array}{l}\text { Informal/Private } \\
\text { information/ Real } \\
\text { content }\end{array}$ & 0.003 & 2.598 & 1 & 743 & 0.107 & 0.059 & 3.087 & 0.063 \\
\hline $\begin{array}{l}\text { Organisational } \\
\text { performance }\end{array}$ & $\begin{array}{l}\text { Gossiping (trust- } \\
\text { worthy infor- } \\
\text { mation, profes- } \\
\text { sional) }\end{array}$ & 0.024 & 14.475 & 1 & 743 & 0.000 & 0.156 & 2.006 & 0.122 \\
\hline $\begin{array}{l}\text { Organisational } \\
\text { performance }\end{array}$ & $\begin{array}{l}\text { Gossiping (trust- } \\
\text { worthy infor- } \\
\text { mation, non-pro- } \\
\text { fessional) }\end{array}$ & 0.019 & 8.375 & 1 & 743 & 0.004 & 0.138 & 2.038 & 0.124 \\
\hline
\end{tabular}

Source: own study.

The numerical results of the test model are presented in Figure 3.

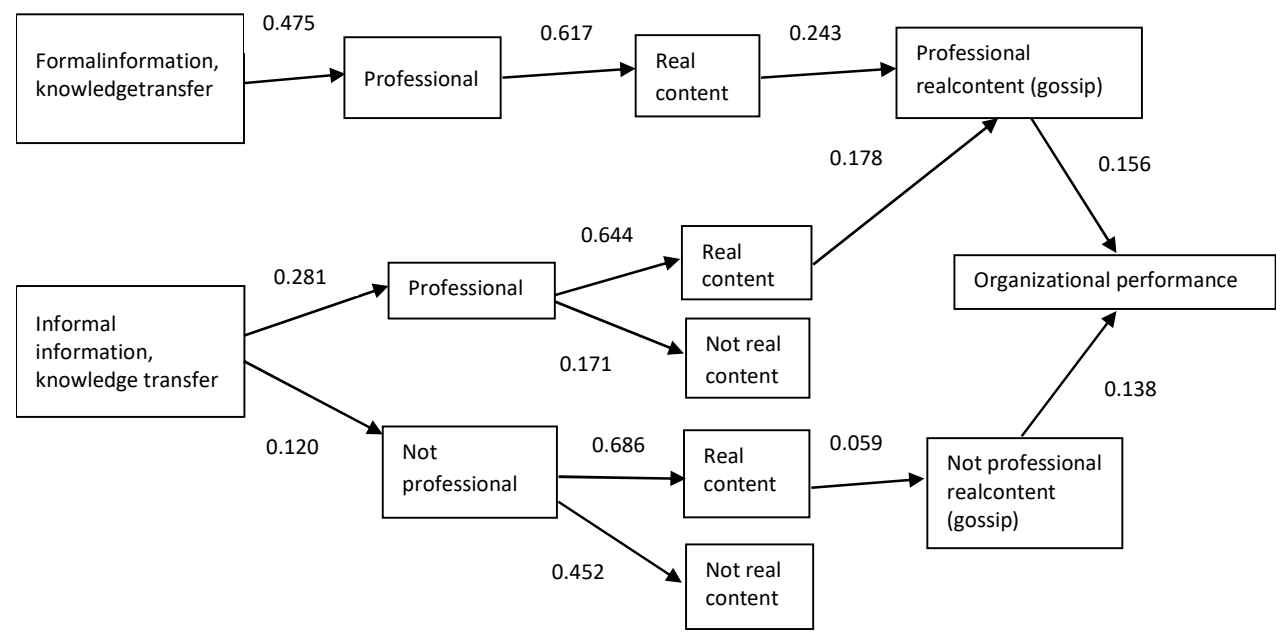

Figure 3. The Testing model

Source: own elaboration.

Respondents of the survey showed a great deal of willingness to share formal information, especially sharing information with professional content. Professional information is shared if it has real content but the willingness is not too high in this case. Professional and non-professional information is eagerly distributed in an informal way, independently of their real or non-real content. Only gossip with personal information and real content influences weakly organisational performance. The respondents share real content professional information in a formal way with the following groups in the following order: a colleague/friend in the same position, a colleague/friend in a higher position, line manager. 
Real content professional information the respondent share in informal way with the same groups mentioned above: a colleague/friend in the same position, a colleague/friend in a higher position, line manager. Results can be seen in Table 5.

Table 5. Characteristics of sharing professional information in a formal and informal way (average)

\begin{tabular}{|l|c|c|}
\hline \multicolumn{1}{|c|}{ Criteria } & Formal & Informal \\
\hline Colleague/friend in the same position & 3.15 & 3.03 \\
\hline A non-friend colleague in a lower position & 3.06 & 2.97 \\
\hline A non-friend colleague in a higher position & 3.09 & 3.00 \\
\hline Colleague/friend in the same position & 3.45 & 3.36 \\
\hline Colleague/friend in lower position & 3.34 & 3.28 \\
\hline Colleague/friend in a higher position & 3.40 & 3.32 \\
\hline Line managers & 3.37 & 3.21 \\
\hline Higher position leaders & 3.23 & 2.99 \\
\hline Owners & 2.91 & 2.77 \\
\hline Friend not working at the same workplace & 2.51 & 2.54 \\
\hline Acquaintance not working at the same workplace & 2.38 & 2.45 \\
\hline Family & 2.57 & 2.66 \\
\hline Nobody & 2.04 & 2.03 \\
\hline
\end{tabular}

Source: own study.

Personal information with real content is shared informally with a colleague/friend or colleague/friend working at the same level in the organisation.

Approximately $10 \%$ of the respondents reported that they used to exchange information this way, while every third of the respondents discuss the information this way occasionally. No significant difference between the surveyed nations was detected regarding the issue (t: $0.686 \mathrm{df}: 743$ sign.: $0.493 \mathrm{p}>0.05$ ).

Gossiping is part of organisational life. The question is what kind of impact it has on everyday life of the organisation. The impact of shared information on different factors had to be evaluated on a 5-point scale by the respondents of the survey. The respondents had to choose the most appropriate answer, where 1 = gossiping results in conflict and 5 = gossiping is necessary. The averages obtained are presented in Table 6 .

The results show that it is not possible to declare that workplace gossip has positive and added value to company performance, even real content information is passed on in the form of gossip. It is clearly reflected by the results that the real content of information can strengthen the positive attitude towards gossip within the organisation. At the same time, the results also indicate that the respondents do not completely reject gossip with fake content. There is no consensus among the respondents that gossip results in conflict. The table clearly shows that gossip can damage the organisational trust and teamwork, which are based on cooperation, communication and loyalty among the employees. The positive factors developed can go in the wrong direction. Although gossiping has no positive impact on the organisational culture, we do not avoid it. Approximately, a third of the respondents reported parallel gossiping in the organisation. How do the respondents feel about workplace gossip? $12 \%$ of the respondents felt positively about gossiping, while $34 \%$ expressed a negative opinion. $40 \%$ of the respondents morally rejected gossiping. 
Table 6. The impact of gossip in organisations (average)

\begin{tabular}{|l|c|c|c|c|}
\hline \multicolumn{1}{|c|}{ Factors } & $\begin{array}{c}\text { Real content, } \\
\text { not professional }\end{array}$ & $\begin{array}{c}\text { Real content, } \\
\text { professional }\end{array}$ & $\begin{array}{c}\text { Not real, not } \\
\text { professional }\end{array}$ & $\begin{array}{c}\text { Professional, } \\
\text { not real content }\end{array}$ \\
\hline Organisational culture & 2.77 & 3.01 & 2.27 & 2.15 \\
\hline Teamwork & 2.69 & 3.01 & 2.18 & 2.09 \\
\hline Employee career & 2.72 & 2.98 & 2.35 & 2.24 \\
\hline Remuneration of employees & 2.75 & 2.91 & 2.43 & 2.32 \\
\hline Organisational trust & 2.74 & 2.97 & 2.28 & 2.19 \\
\hline $\begin{array}{l}\text { Other methods of knowledge } \\
\text { sharing }\end{array}$ & 2.86 & 3.03 & 2.41 & 2.36 \\
\hline Internal communication & 2.84 & 3.00 & 2.28 & 2.23 \\
\hline Employee performance & 2.76 & 2.99 & 2.28 & 2.23 \\
\hline $\begin{array}{l}\text { Performance efficiency of the or- } \\
\text { ganisation }\end{array}$ & 2.76 & 3.05 & 2.39 & 2.29 \\
\hline
\end{tabular}

Source: own study.

\section{Discussion}

The results show that the hypotheses formulated by the authors can be confirmed. Based on the research results, formal knowledge sharing seems to be more characteristic among employees than the informal one. Hypothesis $\mathrm{H} 1$ is confirmed. Regardless of the formal or informal knowledge sharing method, the real content of transferred information is very important to the respondents. This result is presented in the regression model (linear relationships between the features and content of information). It means that the respondents transfer real information first, especially in the case of professional knowledge. This way hypothesis $\mathrm{H} 2$ is confirmed. The impact of gossip on organisational operations is rather negative according to the research results. Both linear analysis (effects of gossip and organisational performance) and average investigations confirmed that gossip has a negative effect on organisational performance. It means that hypothesis $\mathrm{H} 3$ is confirmed.

Unfortunately, most of the organisations participating in the research do not address the issue of workplace gossip and do not deal with the consequences of it. On the theoretical level there is an overlap between the concepts of informal knowledge sharing, informal communication and the informal networks (Taminiau et al., 2007), which indicates that further research is required in this field. Although the impact of gossip in organisational operations is a discussed issue, the researchers stop at defining the impact and declaring the existence of this phenomenon.

Werr and Sjernberg (2003) emphasize the importance of knowledge sharing in their research, especially the need to gain practical experience. This need is also confirmed in this research. The scientific literature provides evidence of the correlation of informal knowledge sharing and the operation of informal networks that explains the natural existence of workplace gossip (Awazu, 2004; Bresnen, 2003) (as cited in Wabwezi, 2011, p. 16). Further research has also confirmed the relevance of knowledge sharing and its occurrence in the form of gossip in practice, which is also proved by this research.

The research conducted by McEvily \& Reagans (2003); Peracek, Noskova \& Mucha (2017). proved that business relations between employees and friendships broaden the 
opportunity of knowledge sharing, especially in an organisational culture based on trust. According to Krogh et al. (2000) the open organisational culture is a prerequisite of knowledge sharing, which later was confirmed by further studies. The authors achieved similar results in their earlier research that can confirm the fact similar to current results about the correlation of gossiping and trust. This can also be confirmed by the existing cultural differences. Keeping distance is at a lower level with Hungarian respondents, which benefits formal and informal knowledge sharing as well. Individualism is at a lower level with the Slovak respondents, which benefits more informal knowledge sharing. The strength of these correlations requires further analysis of a larger sample.

Truran (1998) claimed decades ago that knowledge sharing through ad hoc channels is undergoing a radical transformation, enabled by communication via mail and telephone. These channels provide a possibility for an increased presence of gossip, gaining an institutionalised form in organisations, Krogh et al. (2000) (as cited in Wabwezi, 2011, p. 16). This means that e-gossip is present as a natural phenomenon and its corporate impact is visible, but its characteristics have not been proved in this study. Perhaps, these issues have not been studied properly in the organisations involved in this research.

Based on their experience, Werr and Sjernberg (2003) concluded that the most important source of knowledge acquisition is the emergence of creative ideas through informal relationships. They emphasize that sharing experience is much more common through informal channels, e.g. spontaneous conversations during lunch or coffee break. This kind of experience proves the existence of tacit knowledge, which becomes explicit during communication with colleagues. This also underlines the importance of informal knowledge sharing that makes it easier to understand the knowledge sharing process (Werr \& Sjernberg, 2003, p. 894, as cited in Wabwezi, 2011, pp. 16-17). In recent years, an important field of research is focusing on sharing tacit knowledge as well as demonstrating its practical significance, which also affects the workplace gossip. The leaders of organisations do not appreciate the importance of this behavior appropriately and consider it to be a harmful organisational feature rather than an exploitable possibility.

The opposite outcome is achieved when it is prohibited or punished by the management. The goal is to achieve positive benefits that will be visible when the economic impact of gossiping can be confirmed.

\section{CONCLUSIONS}

The current study presents some of the results of the survey conducted in 2018, which focused on the transfer of formal and informal knowledge/information. The hypotheses based on the results above were confirmed by the authors.

The survey also pointed out that we are more likely to share information with professional content than private information. However, the willingness to share it is determined by the content of the information.

Although formal information sharing is more popular than informal, gossiping is also a popular activity in workplaces. We practice it, even if we know that this form of informal information sharing has no positive effect on the organisation.

The results have shown that soft elements of the organisation can be damaged by gossiping, especially those factors that might take a lot of time to rebuild and can result in 
a loss for the company. Despite the fact that gossiping does not necessarily have a positive influence, we cannot stop doing this activity.

Despite its damaging nature, most of people do not morally reject gossiping. This might be the reason why $60 \%$ of the organisations involved in the survey do not solve the consequences of workplace gossip on the management level. As an interesting result of the survey we can declare no significant differences between the countries in terms of their attitude towards formal and informal knowledge transfer and gossip. Cultural differences have an influence on these processes, but further research is required to address the issue in detail. Managers and leaders should participate in trainings to understand the significance of workplace gossip in order to gain experience and handle the situations effectively.

The research limitations are: (1) Sample size: We could not gather a large enough sample since the number of the respondents was limited. The chosen snowball sampling method did not prove to be transparent. It cannot ensure a representative sample. (2) The lack of prior research studies on the topic: We could not find any research dealing with the economic consequences of informal knowledge sharing or gossip. Therefore we could not compare our results with former research results. (3) Measuring the consequences of workplace gossip is difficult. Further research with a larger sample is required to examine positive and negative effects of workplace gossip.

\section{REFERENCES}

A gonosz pletyka a terjesztőjét is tönkreteszi. (2008). Retrieved from InfoRádió/MTI. https://infostart.hu/tudomany/2008/07/12/a-gonosz-pletyka-a-terjesztojet-is-tonkreteszi-212189 on November 22, 2018.

A pletyka hatásosabb az igazságnál. (2007). Retrieved from http://eletmod.transindex.ro/?hir=9458 on November 23, 2018.

A pletyka jótékony hatásai. (2018). Mindennapi Pszichológia. Retrieved from http://mipszi.hu/hir/ 120503-pletyka-jotekony-hatasai on May 13, 2018.

Awazu, Y. (2004). Informal network players, knowledge integration, and competitive advantage. Journal of Knowledge Management, 8 (3) 62-70.

Azudin, N., Ismail, M.N., \& Taherali, Z. (2009). Knowledge sharing among workers: a study on their contribution through informal communication in Cyberjaya, Malaysia. Knowledge Management \& E-Learning: An International Journal, 1(2), 139-162.

Babalola, M.T., Ren, S., Kobinah, T., Qu, Y.E., Garba, O.A., \& Guo, L. (2019). Negative workplace gossip: Its impact on customer service performance and moderating roles of trait mindfulness and forgiveness. International Journal of Hospitality Management, 80(2), 136-143.

Barna, I., \& Székelyi, M. (2008). Túlélökészlet az SPSS-hez. Budapest: Typotex Kiadó.

Beersma, B., \& Van Kleef, G.A. (2012). Why People Gossip: An Empirical Analysis of Social Motives, Antecedents, and Consequences. Journal of Applied Social Psychology, 42(11), 2640-2670.

Bencsik, A. (2015). Tudásmenedzsment elméletben és gyakorlatban. Budapest: Akadémiai Kiadó.

Bertolotti, T., \& Magnani, L. (2014). An epistemological analysis of gossip and gossip-based knowledge. Synthese, 191, 4037-4067.

Bodnár, T. (2016). Stages of career path through useful crises. Acta Oeconomica Universitatis Selye, $5(1), 20-28$. 
Bresnen, M., Edelman, L., Newell, S., Scarbrougha, H., \& Swana, J. (2003). Social practices and the management of knowledge in project environments. International Journal of Project Management, 21(3), 157-166.

Cuervo-Cazurra, A., \& Ramamurti, R. (2014). Understanding Multinationals from Emerging Markets. Cambridge: Cambridge University Press.

Dunbar, R.I.M. (2004). Gossip in Evolutionary Perspective. Review of General Psychology, 8(2), 100-110.

Ellwardt, L., Labianca, G.J., \& Wittek, R. (2012). Who are the objects of positive and negative gossip at work?: A social network perspective on workplace gossip. Social Networks, 34(2), 193-205.

Ellwardt, L., Steglich, Ch., \& Wittek, R. (2012). The co-evolution of gossip and friendship in workplace social networks. Social Networks, 34, 623-633.

Eraut, M. (2000). Non-formal learning and tacit knowledge in professional work. British Journal of Educational Psychology, 70, 113-136.

Feinberg, M., \& Willer, R. (2010). The Good of Gossip? The Benefits of this Unlikely Prosocial Behavior. Unpublished manuscript. Berkeley: Department of Psychology University of California.

Feinberg, M., Willer, R., \& Schultz, M. (2014). Gossip and Ostracism Promote Cooperation in Groups. Psychological Science, 25, 656-664.

Feinberg, M., Willer, R., Stellar, J.E., \& Keltner, D. (2012). The virtues of gossip: reputational information sharing as prosocial behavior. Journal of Personality and Social Psychology, 102, 5, 1015-1030.

Feinberg, M., Willer, R., Stellar, J.E., \& Keltner, D. (2014). Gossip and Ostracism Solve the Cooperation Problem. Psychological Science, 25(3), 1-9.

Georganta, K., Panagopoulou, E., \& Montgomery, A. (2014). Talking behind their backs: Negative gossip and burnout in Hospitals. Burnout Research, 1(2), 76-81.

Grosser, T.J., Lopez-Kidwell, V., \& Labianca, G. (2010). A Social Network Analysis of Positive and Negative Gossip in Organizational Life. Group \& Organization Management, 35(2), 177-212. https://doi.org/10.1177/1059601109360391

Grosser, T.J., Lopez-Kidwell, V., Labianca, G.J., \& Ellwardt, L. (2012). Hearing it through the grapevine: Positive and negative workplace gossip. Organizational Dynamics, 41(1-3), 52-61.

Hitka, M., Lorincová, S., \& Ližbetinová, L. (2017). Manager's data in human resource management from the perspective of the work position. Acta Oeconomica Universitatis Selye, 6(2), 69-80.

Kiymaz, H. (2001). The effects of stock market rumors on stock prices: evidence from an emerging market. Journal of Multinational Financial Management, 11(1), 105-115.

Lazanyi, K., \& Fulop, M. (2017). Why don't we trust others? Acta Oeconomica Universitatis Selye, 6(1), 61-70.

Lorincová, S. (2018). Human resource and corporate culture: Gender-based differences in the assessment. Central European Journal of Labour Law and Personnel Management, 1(1), 28-45. https://doi.org/10.33382/cejllpm.2018.01.03

Michelson, G., Iterson, A., \& Waddington, K. (2010). Gossip in Organizations: Contexts, Consequences, and Controversies. Group \& Organization Management, 35(4), 371-390. https://doi.org/10.1177/1059601109360389

Novotna, M., \& Volek, T. (2018). Efficiency of production factors in the EU. DETUROPE-The Central European Journal of Regional Development and Tourism, 10(2), 147-168.

Parker, C.B. (2014). Stanford research: Hidden benefits of gossip, ostracism. Stanford: Stanford Report.

Peráček, T., Nosková, M., \& Mucha, B. (2017). Selected issues of Slovak business environment. In V. Potocan, P. Kalinic, \& A. Vuletic (eds.), Economic and Social Development (pp 254-259). Arazdin: Varazdin Development and Entrepreneurship Agency. 
Pletykálni jó? (2008). Erdély online. Retrieved from http://www.erdon.ro/pletyklni-j/news20080712-03162958 on November 22, 2018.

Probst, G., Raub, S., \& Romhardt, K. (2006). Wissen Managen Wie Unternehmen ihre wertvollste Ressource optimal nutzen. Wiesbaden: Gabler GmbH.

Pusztai, F., Gerstner, K. et al. (Eds.) (2006). Magyar értelmező kéziszótár (3). Budapest: Akadémiai Kiadó.

Scholtes, S. (20.09.2006). Market gossip goes high-tech. Financial Times. New York. Retrieved from https://www.ft.com/content/d9db82e0-48e4-11db-a996-0000779e2340 on December 12, 2018.

Seilerová, M. (2019). The Consequences of Psychosocial Risks in the Workplace in Legal Context. Central European Journal of Labour Law and Personnel Management, 2(1), 47-60. https://doi.org/10.33382/cejllpm.2019.02.04

Sommerfeld, R.D., Krambeck, H.J., Semmann, D., \& Milinski, M. (2007). Gossip as an alternative for direct observation in games of indirect reciprocity. PNAS, 104 (44), 17435-17440.

Szvetelszky, Zs. (2017). Rejtett szervezetek - Az informális kommunikáció hatalma. Budapest: Typotex Elektronikus Kiadó Kft., 208.

Taminiau, Y., Smit, W., \& Lange, A. (2009). Innovation in Management Consulting Firms through Informal Knowledge Sharing. Journal of Knowledge Management, 13(1), 42-55.

Tassiello, V., Lombardi, S., \& Costabile, M. (2018). Are we truly wicked when gossiping at work? The role of valence, interpersonal closeness and social awareness. Journal of Business Research, 84(3), 141-149.

Tierny, J. (2007). Facts Prove No Match for Gossip, It Seems, The New York Times. Retrieved from https://www.nytimes.com/2007/10/16/science/16tier.html on November 23, 2018.

Truran, W.R. (1998). Pathways for knowledge: How companies learn through people. Engineering Management Journal, 10(4), 15-20.

Vlacseková, D. (2019). Comparative analysis of motivation of civil servants and public servants in the local state administration - case study of Slovakia. Central European Journal of Labour Law and Personnel Management, 2(1), 74-93. https://doi.org/10.33382/cejllpm.2019.02.06

Volek, T., \& Novotna, M. (2016). Labour productivity as a factor of sector competitiveness. 10th International Days of Statistics and Economics, 1997-2006.

Wabwezi, A. (2011). The role of knowledge sharing in fostering innovation in higher education: $A$ case study of Tallinn University. Halden: Høgskolen i Østfold.

Werr, A., \& Stjernberg, T. (2003). Exploring management consulting firms as knowledge systems. Organization Studies, 24(6), 881-908.

Wilkie, D. (2019). Workplace Gossip: What Crosses the Line? Society for Human Resource Management. Retrieved from https://www.shrm.org/resourcesandtools/hr-topics/employeerelations/pages/office-gossip-policies.aspx on January 21, 2019.

Xu, F., Adolphs, P., Uszkoreit, H., Cheng, X., \& Li, H.X. (2009). Gossip Galore: A Conversational Web Agent for Collecting and Sharing Pop Trivia. In J. Filipe, A. Fred, \& B. Sharp (Eds.), 5. Proceedings of ICAART 2009 - First International Conference on Agents and Artificial Intelligence, Porto, Portugal, INSTICC Press.

Yi, J. (2015). A Measure of Knowledge Sharing Behavior: Scale Development and Validation. In J.S. Edwards (Ed.), The Essentials of Knowledge Management. OR Essentials Series. London: Palgrave Macmillan. 


\section{Authors}

The contribution share of authors is as follows: A. Bencsik $-25 \%, \mathrm{~T}$. Juhász $-25 \%$,

$$
\text { L. Mura-25\%, A. Csanádi }-25 \% \text {. }
$$

\section{Andrea Bencsik}

Professor of Management, PhD. in Sectoral Economics. Her research interests include knowledge management, organisational behaviour, human resource management, change management.

Correspondence to: prof. dr. Andrea Bencsik, CSc., PhD., J. Selye University Komarno, Faculty of Economics, Bratislavska cesta 3322. SK-94501 Komarno, e-mail: bencsika@ujs.sk; University of Pannonia Veszprém, Faculty of Management, e-mail: Bencsik.andrea@gtk.uni-pannon.hu ORCID (1) http://orcid.org/0000-0001-8204-3706

\section{Timea Juhász}

Freelancer, PhD. in Sectoral Economics. Her research interests include knowledge management, human resource management, family-friendly organisations.

Correspondence to: Dr. Timea Juhasz, e-mail: juhasz.timi@hotmail.com

ORCID (1) http://orcid.org/0000-0001-5386-0678

\section{Ladislav Mura}

Associate professor of Business Economics, PhD. In Sectoral Economics. His research interests include human resource management, small and medium-sized enterprises, family businesses and international entrepreneurship.

Correspondence to: Assoc. prof. PhDr. Ing. Ladislav Mura, PhD., Pan-European University in Bratislava, Faculty of Economics and Business, Tematínska 10, 85105 Bratislava, e-mail: ladislav.mura@gmail.com

ORCID (1) http://orcid.org/0000-0002-2453-8740

\section{Ágnes Csanádi}

Associate professor of Business Economics, PhD. in Sectoral Economics. His research interests include public service, finance and accounting, management.

Correspondence to: assoc. prof. Agnes Csanadi PhD., Budapest Business School, Zalaegerszeg Faculty of Business Administration, H-8900 Zalaegerszeg, Gasparich Márk street 18/A., ZFBA campus, e-mail: csanadi.agnes@uni-bge.hu

ORCID (1) http://orcid.org/0000-0002-6940-0796

\section{Acknowledgements and Financial Disclosure}

Scientific Paper was elaborated and financed within the framework of the project VEGA 1/0813/19 Managing the development of innovative and start-up forms of businesses in international environment and verification of INMARK concept.

\section{Copyright and License}

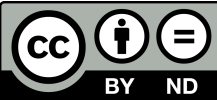

This article is published under the terms of the Creative Commons

Attribution - NoDerivs (CC BY-ND 4.0) License

http://creativecommons.org/licenses/by-nd/4.0/

Published by the Centre for Strategic and International Entrepreneurship - Krakow, Poland 